\title{
Optimization of Chemical Parameters for the Production of Citric acid using Box-Behnken Design
}

Gopinadh $\mathbf{R}^{1 *}$, Ayyanna $\mathbf{C}^{2}$, Ramakrishna $\mathbf{C h}^{3}$, Narayana Saibaba KV ${ }^{1}$, Ravi Vital Kandisa ${ }^{1}$ and Jagadhi $\mathbf{R}^{4}$

${ }^{1}$ Central Research Laboratory, Industrial Biotechnology, GITAM Institute of Technology, GITAM University, Visakhapatnam-530045, Andhra Pradesh, India ${ }^{2}$ Department of Chemical Engineering, Andhra University, Visakhapatnam-530003, Andhra Pradesh, India

${ }^{3}$ Director, Directorate of UGC affairs and research activities, GITAM University, Visakhapatnam-530045, Andhra Pradesh, India

${ }^{4}$ Department of Pharmaceutical Sciences, Andhra University, Visakhapatnam-530003, Andhra Pradesh, India

\begin{abstract}
Statistical experimental design was employed for the improvement of citric acid production from Madhuca indica through submerged fermentation process using mutant fungi Aspergillus niger MTCC 282. Efficient production of citric acid by mutant Aspergillus niger MTCC 282 grown on a sugar rich byproduct requires the supplementation of the optimized quantities of nutrients. Optimization of chemical parameters for the production of citric acid was done by Box-Behnken design. Box-Behnken design was used to statistically compare different combinations of four different nutrients, namely Ammonium sulphate $\left(\left(\mathrm{NH}_{4}\right)_{2} \mathrm{SO}_{4}\right), \mathrm{Magnesium}$ $\left(\mathrm{Mg}^{2+}\right)$, Ethylene diamine tetra acetic acid (EDTA) and Potassium phosphate $\left(\mathrm{KH}_{2} \mathrm{PO}\right)$, for the maximum production of citric acid. The optimum nutrient concentrations obtained using the Box-Behnken design were Ammonium sulphate $\left(\left(\mathrm{NH}_{4}\right)_{2} \mathrm{SO}_{4}\right) 0.2138 \mathrm{~g} / \mathrm{l}$, Magnesium $\left(\mathrm{Mg}^{2+}\right) 0.1896 \mathrm{~g} / \mathrm{l}$, Ethylene diamine tetra acetic acid (EDTA) $0.3968 \mathrm{~g} / \mathrm{l}$ and Potassium phosphate $\left(\mathrm{KH}_{2} \mathrm{PO}_{4}\right) 3 \mathrm{~g} / \mathrm{l}$. Under the optimum conditions, mutant Aspergillus niger MTCC 282 produced the maximum citric acid of $75 \mathrm{~g} / \mathrm{l}$ of citric acid/ kg substrate at $\mathrm{pH} 4$.
\end{abstract}

Keywords: Aspergillus niger; Box-Behnken design; Submerged fermentation; Mahua flower; Citric acid

\section{Introduction}

A variety of fungi is reported to produce organic acids such as citric acid, oxalic acid, succinic acid and malic acid. Among them, citric acid production using the filamentous fungi Aspergillus niger is well known and is widely used in food, beverages, chemical and pharmaceutical industries [1]. Citric acid is a biodegradable, environmentally accepted and versatile organic acid produced by fermentation [2]. Presently citric acid from mutant Aspergillus niger MTCC 282 is economically produced by using various sources. However, the global demand for citric acid is growing faster than its production, implying more economical processes are required to supplement the present processes [3-6]. Hence in the present study a novel source such as Madhuca indica was tested for the production of citric acid.

Mahua (Madhuca indica) trees are distributed all over the world. Annual production of dry mahua flowers in India is about 2 million tonnes. The flowers, which are succulent, are eaten raw or cooked. They are used in the preparation of distilled liquors and vinegar. They are also used as feed for livestock. But so far they have not been used for fermentation for the production of citric acid and other metabolites. Carbohydrate source has an important effect on the production of citric acid by Aspergillus niger [7]. Flowers of Madhuca indica are rich in sugars and contain appreciable amounts of vitamins and calcium [8,9]. Madhuca indica is of high nutrient value and has vast potential for good quality of citric acid, which will find extensive export market. It is of low cost, economically and abundantly available substrate.

The most important chemical fermentation parameters influencing the growth of Aspergillus niger on a liquid substrate and production of citric acid are: nutrients, substrate composition, nitrogen, phosphorous, potassium and other salts $[10,11]$. Commercial production of citric acid is performed mainly with Aspergillus niger. The fungus Aspergillus niger is grown on sugar rich byproducts using submerged fermentation to produce citric acid. To produce maximum amount of citric acid, it is essential to study the influence of physical and chemical environments on citric acid production [11]. Nevertheless, this process requires optimization of nutrients. Therefore, experiments were conducted to find the response of Aspergillus niger for the production of citric acid at different combinations of four different nutrients such as Ammonium sulphate $\left(\left(\mathrm{NH}_{4}\right)_{2} \mathrm{SO}_{4}\right)$, Magnesium $\left(\mathrm{Mg}^{2+}\right)$, Ethylene Diamine Tetra acetic Acid (EDTA), Potassium phosphate $\left(\mathrm{KH}_{2} \mathrm{PO}_{4}\right.$.

The traditional one-factor-at-a-time technique used for optimizing the variables is not only time consuming but also often easily confuses the alternative effects between the components. This method requires a large number of experimental works to determine the optimum levels. The drawbacks of the one factor method can be eliminated by optimizing all the effecting parameters collectively by response surface methodology.

\section{Materials and Methods}

\section{Microorganism and preparation of inoculum}

The fungus Aspergillus niger MTCC 282 was obtained from the Microbial Type Culture Collection (MTCC) Chandigarh, India. The fungus used in this study is a UV-mutant strain. Mutants are produced by mutagenic treatment by the method as described by Hamissa [12]. The organism was maintained on Potato Dextrose Agar (PDA) slants (HIMEDIA, India) at $4^{\circ} \mathrm{C}$. The culture was inoculated on PDA slants at $30^{\circ} \mathrm{C}$ for 10 days. $1 \mathrm{ml}$ of $0.1 \%$ Tween 80 (Qualigens, India) solution was added to each slant. Spores were scrapped off, suspended in water at $10 \mathrm{ml}$. The strain was sub-cultured for every two months interval of time.

*Corresponding author: Gopinadh R, Central Research Laboratory Industrial Biotechnology, GITAM Institute of Technology, GITAM University, Visakhapatnam-530045, Andhra Pradesh, India, Tel: 986-626-4077; E-mail: gopinadh@gitam.edu

Received May 27, 2015; Accepted July 21, 2015; Published July 27, 2015

Citation: Gopinadh R, Ayyanna C, Ramakrishna Ch, Narayana Saibaba KV Ravi Vital Kandisa, et al. (2015) Optimization of Chemical Parameters for the Production of Citric acid using Box-Behnken Design. J Bioprocess Biotech 5: 244 doi:10.4172/2155-9821.1000244

Copyright: @ 2015 Gopinadh R, et al. This is an open-access article distributed under the terms of the Creative Commons Attribution License, which permits unrestricted use, distribution, and reproduction in any medium, provided the original author and source are credited. 
Citation: Gopinadh R, Ayyanna C, Ramakrishna Ch, Narayana Saibaba KV, Ravi Vital Kandisa, et al. (2015) Optimization of Chemical Parameters for the Production of Citric acid using Box-Behnken Design. J Bioprocess Biotech 5: 244 doi:10.4172/2155-9821.1000244

\section{Production medium}

Madhuca indica was used as carbon source for fermentation. Flowers of Madhuca indica were collected from agency area in Visakhapatnam, Andhra Pradesh. These flowers were washed thoroughly under tap water and juice was extracted using mortar and pestle. The juice was collected in a beaker and was filtered using Whatman filter paper 50 . The filtrate was collected for citric acid production.

\section{Fermentation conditions for submerged fermentation}

The submerged fermentation was performed in $250 \mathrm{ml}$ Erlenmeyer flasks. $100 \mathrm{ml}$ of production medium is supplemented with Ammonium sulphate $\left(\left(\mathrm{NH}_{4}\right)_{2} \mathrm{SO}_{4}\right)$, Magnesium $\left(\mathrm{Mg}^{2+}\right)$, Ethylene diamine tetra acetic acid (EDTA), Potassium phosphate $\left(\mathrm{KH}_{2} \mathrm{PO}_{4}\right)$ to different flasks The $\mathrm{pH}$ of the medium was adjusted to 4.0 by $1 \mathrm{M} \mathrm{HCl}$ and autoclaved at $121^{\circ} \mathrm{C}$ for 15 minutes at $15 \mathrm{psi}$. After autoclaving, the flasks were inoculated with $1 \mathrm{ml}\left(1.0 \times 10^{6}\right.$ spores $\left./ \mathrm{ml}\right)$ of mutant Aspergillus niger MTCC 282 inoculum and were incubated at $30^{\circ} \mathrm{C}$ for 264 hours on an orbital shaking incubator at a speed of $150 \mathrm{rpm}$.

\section{Analytical procedures}

A known volume of fermentation broth was removed for every 24 hours under aseptic conditions and centrifuged at $6000 \mathrm{rpm}$. The supernatant was analyzed for the estimation of citric acid and total reducing sugars. Citric acid was estimated by the method as described by Marrier and Boulet [13]. Reducing sugars were determined as described by Miller [14].

\section{Experimental design and optimization}

Response Surface Methodology (RSM) is a collection of mathematical and statistical techniques for empirical model building. Response surface methods are employed to find factor settings (operating conditions) that produce the best response [15]. BoxBehnken Design (BBD) method is used to examine the relationship between one or more response variables and a set of quantitative experimental variables or factors [16]. In order to describe the nature of response surface in the experimental region and elucidate the optimal concentrations of the most significant independent variables Box-Behnken design was used. In the present study Box-Behnken design was used to optimize medium constituents and conditions for production of citric acid.

Preliminary investigations indicated that Ammonium sulphate $\left(\left(\mathrm{NH}_{4}\right)_{2} \mathrm{SO}_{4}\right)$, Magnesium $\left(\mathrm{Mg}^{2+}\right)$, Ethylene diamine tetra acetic acid (EDTA), Potassium phosphate $\left(\mathrm{KH}_{2} \mathrm{PO}_{4}\right)$ are highly significant variables for citric acid production. Thus these variables were chosen for optimization studies and designated as $\mathrm{X}_{1}, \mathrm{X}_{2}, \mathrm{X}_{3}$ and $\mathrm{X}_{4}$ respectively. The parameters and their range in coded values used in the experiment were described in Table 1.

Coding of the variables was done according to the following equation (1)

$$
\begin{aligned}
& x_{i}=\left(\mathrm{X}_{\mathrm{i}}-\left(\overline{X_{i}}\right) / \Delta \mathrm{X}_{\mathrm{i}} \quad \mathrm{i}=1,2,3 \ldots . \mathrm{k},\right. \\
& \text { Where } \\
& \mathrm{X}_{\mathrm{X}}=\text { dimensionless value of an independent variable } \\
& \overline{X_{i}}=\text { real value of an independent variable } \\
& \begin{aligned}
\Delta \mathrm{X}_{\mathrm{i}} & =\text { Real value of an independent variable at centre point } \\
& =\text { Step change }
\end{aligned}
\end{aligned}
$$

To construct the response surface model, the following secondorder polynomial equation was fitted to the data using multiple regressions.

$$
\begin{aligned}
& Y=\beta_{o}+\sum_{i=1}^{k} \beta_{i} x_{i}+\sum_{i=1}^{k} \beta_{i i} X_{i}^{2}+\sum_{i<} \sum_{j} \beta_{i j} X_{i} X_{j}+\varepsilon \\
& \text { Where }
\end{aligned}
$$

$\mathrm{Y}=$ response, $\mathrm{X}=$ factors,

$\beta_{k}=$ regression coefficients and

$\varepsilon=$ error term with a normal distribution, mean of 0 , and standard deviation of $\sigma$.

The values of the coefficients as well as the optimum concentrations were calculated using Matlab. The quality of fit of the polynomial model equation was expressed by the coefficient of determination $\mathrm{R}^{2}$.

\section{Results and Discussion}

\section{Effects of nutrient levels on citric acid production}

Box- Behnken design was used to optimize medium constituents for the production of citric acid. In order to approach the optimum response region of citric acid yield, significant independent variables were further explored, each at three levels according to Box-Behnken. Table 2 represents the design matrix of the coded variables together with the experimental results of citric acid yield. All cultures were grown in $100 \mathrm{ml}$ aliquots in triplicates and the averages of the observations were used. According to the applied design, 30 combinations were executed and their observations were fitted to the following second order polynomial model.

$\mathrm{Y}=-2.1695+159.439 \mathrm{X}_{1}-244.357 \mathrm{X}_{2}+28.6463 \mathrm{X}_{3}+39.972 \mathrm{X}_{4}$ $42.2621 \mathrm{X}_{1}{ }^{2}-137.19 \mathrm{X}_{2}{ }^{2}-20.9154 \mathrm{X}_{3}{ }^{2}-4.43352 \mathrm{X}_{4}{ }^{2}-$ $1.45125 \mathrm{X}_{1} \mathrm{X}_{2}+23.5856 \mathrm{X}_{1} \mathrm{X}_{3}-64.986 \mathrm{X}_{1} \mathrm{X}_{4}-37.2275 \mathrm{X}_{2} \mathrm{X}_{3}+110.296 \mathrm{X}_{2} \mathrm{X}_{4}$ $-10.0856 \mathrm{X}_{3} \mathrm{X}_{4}$

The goodness of fit of equation was determined by computing predicted citric acid production values and comparing them to those measured. At the model level, the correlation measures for the estimation of the regression equation are the multiple correlation factor $\mathrm{R}$ and the determination coefficient $\mathrm{R}^{2}$. From Table $3, \mathrm{R}^{2}$ for citric acid production was 0.997 . This value indicates a high degree of correlation between the experimental and predicted values. It is also a measure of fit to the model, which implies a good agreement between the observed and predicted response $[7,17,18]$. The significance and adequacy of the second-order equation was determined by using analysis of variance (ANOVA). The result of the ANOVA is shown in Table 4. Ammonium sulphate, Magnesium, EDTA, $\mathrm{KH}_{2} \mathrm{PO}_{4}$ had shown significant impact on citric acid production by Aspergillus niger MTCC 282 at 72 hours of fermentation.

\section{Response surface curves}

The $3 \mathrm{D}$ response surface plots are the graphical representation of the regression equation used to determine the optimum values of

\begin{tabular}{|l|l|l|l|l|l|}
\hline \multirow{2}{*}{ S.No } & \multirow{2}{*}{ Variable } & \multirow{2}{*}{ Parameter } & \multicolumn{3}{|c|}{ Coded and actual Level } \\
\cline { 5 - 6 } & & $\mathbf{- 1}$ & $\mathbf{0}$ & $\mathbf{1}$ \\
\hline 1 & $\mathrm{X}_{1}$ & Ammonium sulphate $(\mathrm{g} / \mathrm{l})$ & 0.2 & 0.4 & 0.6 \\
\hline 2 & $\mathrm{X}_{2}$ & Magnesium $(\mathrm{g} / \mathrm{l})$ & 0.05 & 0.15 & 0.25 \\
\hline 3 & $\mathrm{X}_{3}$ & $\mathrm{EDTA}_{(\mathrm{g} / \mathrm{l})}$ & 0.2 & 0.4 & 0.6 \\
\hline 4 & $\mathrm{X}_{4}$ & $\mathrm{KH}_{2} \mathrm{PO}_{4}(\mathrm{~g} / \mathrm{l})$ & 2 & 2.5 & 3 \\
\hline
\end{tabular}

Table 1: Coded Values used in Box-Behnken design to optimize the chemical parameters for citric acid production. 
Citation: Gopinadh R, Ayyanna C, Ramakrishna Ch, Narayana Saibaba KV, Ravi Vital Kandisa, et al. (2015) Optimization of Chemical Parameters for the Production of Citric acid using Box-Behnken Design. J Bioprocess Biotech 5: 244 doi:10.4172/2155-9821.1000244

Page 3 of 6

\begin{tabular}{|c|c|c|c|c|c|c|}
\hline Run No & $x_{1}$ & $x_{2}$ & $\mathrm{X}_{3}$ & $x_{4}$ & $\begin{array}{c}\text { Experimental Yield } \\
(\mathrm{g} / \mathrm{l})\end{array}$ & $\begin{array}{c}\text { Predicted Yield } \\
(\mathrm{g} / \mathrm{l})\end{array}$ \\
\hline 1 & 0 & 0 & 0 & 0 & 63.2092 & 63.17875 \\
\hline 2 & 0 & 0 & -1 & -1 & 60.2092 & 59.95509 \\
\hline 3 & -1 & 1 & 0 & 0 & 62.8258 & 63.14466 \\
\hline 4 & -1 & -1 & 0 & 0 & 68.3970 & 68.13571 \\
\hline 5 & 0 & 0 & 0 & 0 & 63.2092 & 63.17875 \\
\hline 6 & 0 & -1 & -1 & 0 & 64.2680 & 64.64021 \\
\hline 7 & 1 & 0 & 1 & 0 & 54.2260 & 54.18126 \\
\hline 8 & 1 & 0 & -1 & 0 & 56.1991 & 56.07438 \\
\hline 9 & 0 & -1 & 0 & -1 & 66.2092 & 66.57774 \\
\hline 10 & 0 & 0 & 1 & 1 & 60.2792 & 60.49529 \\
\hline 11 & 1 & 0 & 0 & -1 & 59.1991 & 59.19458 \\
\hline 12 & 0 & 1 & -1 & 0 & 61.2092 & 61.08021 \\
\hline 13 & 1 & 0 & 0 & 1 & 50.2092 & 50.51754 \\
\hline 14 & 0 & 0 & 0 & 0 & 63.2092 & 63.17875 \\
\hline 15 & 0 & -1 & 1 & 0 & 62.1900 & 62.34935 \\
\hline 16 & 0 & 0 & -1 & 1 & 66.2092 & 66.29237 \\
\hline 17 & 0 & -1 & 0 & 1 & 60.1500 & 59.8683 \\
\hline 18 & -1 & 0 & 1 & 0 & 63.2092 & 63.34207 \\
\hline 19 & 0 & 1 & 1 & 0 & 56.1530 & 55.81115 \\
\hline 20 & 0 & 0 & 0 & 0 & 63.0260 & 63.17875 \\
\hline 21 & 0 & 1 & 0 & 1 & 66.2092 & 65.8488 \\
\hline 22 & -1 & 0 & 0 & -1 & 57.5230 & 57.24503 \\
\hline 23 & 1 & -1 & 0 & 0 & 57.5030 & 57.14611 \\
\hline 24 & 0 & 1 & 0 & -1 & 50.2092 & 50.49904 \\
\hline 25 & -1 & 0 & 0 & 1 & 74.5275 & 74.56239 \\
\hline 26 & -1 & 0 & -1 & 0 & 68.9560 & 69.00888 \\
\hline 27 & 1 & 1 & 0 & 0 & 51.8157 & 52.03896 \\
\hline 28 & 0 & 0 & 0 & 0 & 63.2092 & 63.17875 \\
\hline 29 & 0 & 0 & 1 & -1 & 58.3135 & 58.19225 \\
\hline 30 & 0 & 0 & 0 & 0 & 63.2092 & 63.17875 \\
\hline
\end{tabular}

Table 2: Experimental and Predicted yield of citric acid values.

\begin{tabular}{|c|c|c|c|c|}
\hline Term & Coef & SE Coef & $\mathbf{T}$ & $\mathbf{P}$ \\
\hline Constant & 63.1787 & 0.12676 & 498.418 & 0.000 \\
\hline $\mathrm{X}_{1}$ & -5.5239 & 0.08963 & -61.629 & 0.00 \\
\hline $\mathrm{X}_{2}$ & -2.5246 & 0.08963 & -28.166 & 0.000 \\
\hline $\mathrm{X}_{3}$ & -1.8900 & 0.08963 & -21.086 & 0.000 \\
\hline $\mathrm{X}_{4}$ & 2.1601 & 0.08963 & 24.100 & 0.000 \\
\hline $\mathrm{X}_{1}{ }^{*} \mathrm{X}_{1}$ & -1.6905 & 0.11857 & -14.257 & 0.000 \\
\hline $\mathrm{X}_{2}{ }^{*} \mathrm{X}_{2}$ & -1.3719 & 0.11857 & -11.570 & 0.000 \\
\hline $\mathrm{X}_{3}^{*} \mathrm{X}_{3}$ & -0.8366 & 0.11857 & -7.056 & 0.000 \\
\hline $\mathrm{X}_{4}^{*} \mathrm{X}_{4}$ & -1.1084 & 0.11857 & -9.348 & 0.000 \\
\hline $\mathrm{X}_{1}^{*} \mathrm{X}_{2}$ & -0.0290 & 0.15525 & -0.187 & 0.854 \\
\hline $\mathrm{X}_{1}^{*} \mathrm{X}_{3}$ & 0.9434 & 0.15525 & 6.077 & 0.000 \\
\hline $\mathrm{X}_{1}^{*} \mathrm{X}_{4}$ & -6.4986 & 0.15525 & -41.860 & 0.000 \\
\hline $\mathrm{X}_{2}^{*} \mathrm{X}_{3}$ & -0.7445 & 0.15525 & -4.796 & 0.000 \\
\hline $\mathrm{X}_{2}^{*} \mathrm{X}_{4}$ & 5.5148 & 0.15525 & 35.523 & 0.000 \\
\hline $\mathrm{X}_{3}{ }^{*} \mathrm{X}_{4}$ & -1.0086 & 0.15525 & -6.497 & 0.000 \\
\hline
\end{tabular}

Table 3: Regression analysis for citric acid production.

\begin{tabular}{|l|l|l|l|l|l|l|l|}
\hline S.No & Source & DF & Seq SS & Adj SS & Adj MS & F & P \\
\hline 1 & Regression & 14 & 875.213 & 875.213 & 62.515 & 648.46 & 0.000 \\
\hline 2 & Linear & 4 & 541.497 & 541.497 & 135.374 & 1404.21 & 0.000 \\
\hline 3 & Square & 4 & 33.287 & 33.287 & 8.322 & 86.32 & 0.000 \\
\hline 4 & Interaction & 6 & 300.429 & 300.429 & 50.072 & 519.38 & 0.000 \\
\hline 5 & Residual Error & 15 & 1.446 & 1.446 & 0.096 & & \\
\hline 6 & Lack-of-Fit & 10 & 1.418 & 1.418 & 0.142 & 25.35 & 0.001 \\
\hline 7 & Pure Error & 5 & 0.028 & 0.028 & 0.006 & & \\
\hline 8 & Total & 29 & 876.659 & & & & \\
\hline
\end{tabular}

Table 4: Analysis of Variance (ANOVA) for citric acid production.

the variables within the ranges considered [19]. The 3D plots for the interactions cyclically between two variables among three the variables are presented in Figures 1-6. The main target of response surface is to hunt efficiently for the optimum values of the variables such that the response is maximized [19]. Each contour curve represents an infinitive number of combinations of the two test variables while the other variable maintained at zero level (center). The maximum predicted value is identified by the surface confined in the smallest ellipse in the contour diagram. Elliptical contours are obtained when there is a perfect interaction between the independent variables [20].

Three-dimensional response surface curves show the interaction between the two variables, while fixing that of the others. Figure 1 shows the interactive effect of $\mathrm{KH}_{2} \mathrm{PO}_{4}$ and EDTA on citric acid production at 72 hours of fermentation. In the plot, an elliptical response surface in the entire region was found from the second order quadratic equation for the citric acid production. The results showed that the citric acid production was considerably affected by varying the concentration of $\mathrm{KH}_{2} \mathrm{PO}_{4}$ and EDTA. The maximum production was obtained at the point of intersection of the major and minor axes of the ellipse [21-24].

The interactive effects of $\mathrm{KH}_{2} \mathrm{PO}_{4}$ and $\mathrm{Mg}^{2+}$ on citric acid production at 72 hours of fermentation with fixed level of EDTA and Ammonium sulphate are shown in Figure 2. $\mathrm{KH}_{2} \mathrm{PO}_{4}$ concentration was found to affect citric acid production nonlinearly at all concentrations of $\mathrm{Mg}^{2+}$. The inhibition by citric acid was due to chelation of $\mathrm{Mg}^{2+}$ which is required to chelate the co-substrate ATP, and is most probably irrelevant under physiological conditions where $\mathrm{Mg}^{2+}$ is present in excess. Increase in the $\mathrm{KH}_{2} \mathrm{PO}_{4}$ concentration from 2 to $3 \mathrm{~g} / \mathrm{l}$ leads to an increase in citric acid production $[25,26]$.

Figure 3 shows the elliptical response surface plot of citric acid production as a function of EDTA and $\mathrm{Mg}^{2+}$ at 72 hours of fermentation. The predicted citric acid production decreased at the lower values of ranges for both EDTA and $\mathrm{Mg}^{2+}$ concentrations [27]. Initial EDTA concentration strongly affected citric acid production by mutant Aspergillus niger MTCC 282. Decrease in the citric acid production is due to the chelation of $\mathrm{Mg}^{2+}$ ions. Optimum yields were obtained when $\mathrm{Mg}^{2+}$ was in low concentration. EDTA and $\mathrm{Mg}^{2+}$ affected the yield of citric acid other than their effect on the growth of mycelium. Their optimum concentrations for maximum citric acid production were interdependent. The maximum production of citric acid was predicted at the EDTA and $\mathrm{Mg}^{2+}$ concentration level of about $0.4 \mathrm{~g} / \mathrm{l}$ and $0.15 \mathrm{~g} / \mathrm{l}$ [28-30].

Figure 4 represents the surface response curve of citric acid production as a function of Ammonium sulphate $\left(\mathrm{NH}_{4}\right)_{2} \mathrm{SO}_{4}$ and $\mathrm{KH}_{2} \mathrm{PO}_{4}$. Citric acid production increased with increased concentrations of $\mathrm{KH}_{2} \mathrm{PO}_{4}$, and decreased concentrations of Ammonium sulphate. The maximum production of citric acid was predicted at the Ammonium 
Citation: Gopinadh R, Ayyanna C, Ramakrishna Ch, Narayana Saibaba KV, Ravi Vital Kandisa, et al. (2015) Optimization of Chemical Parameters for the Production of Citric acid using Box-Behnken Design. J Bioprocess Biotech 5: 244 doi:10.4172/2155-9821.1000244

Page 4 of 6

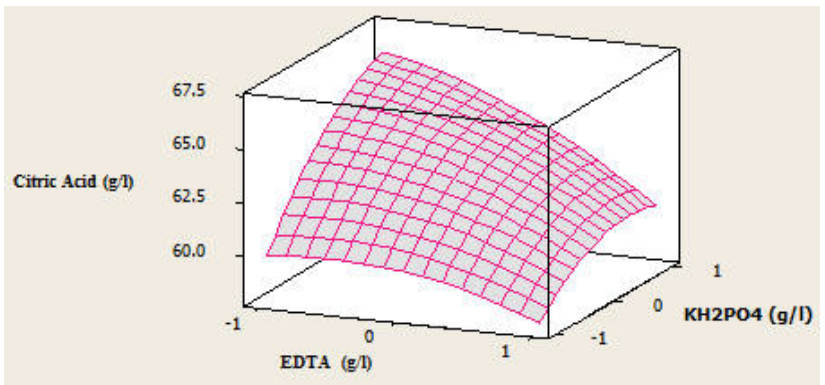

Figure 1: Response surface curve for citric acid production representing the interaction between $\mathrm{KH}_{2} \mathrm{PO}_{4}$ and EDTA at 72 hours.

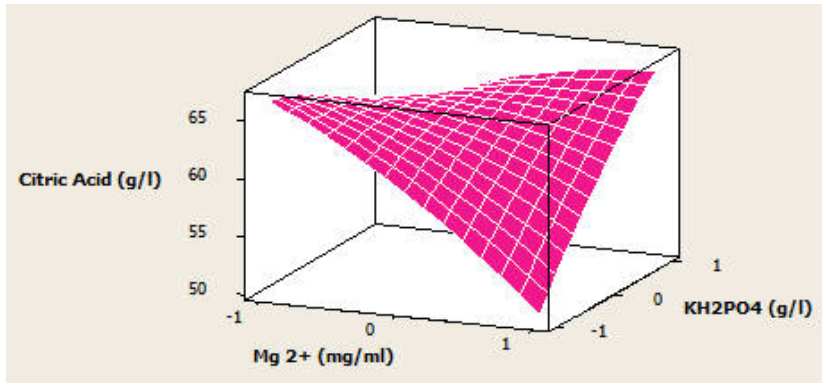

Figure 2: Response surface curve for citric acid production representing the interaction between $\mathrm{KH}_{2} \mathrm{PO}_{4}$ and $\mathrm{Mg}^{2+}$ at 72 hours.

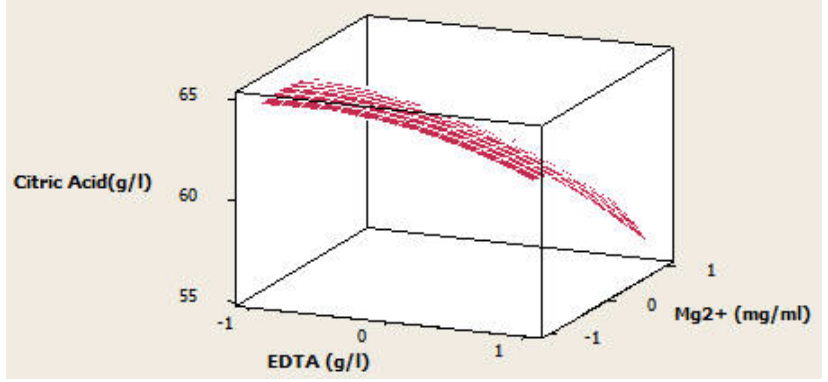

Figure 3: Response surface curve for citric acid production representing the interaction between $\mathrm{Mg}^{2+}$ and EDTA at 72 hours.

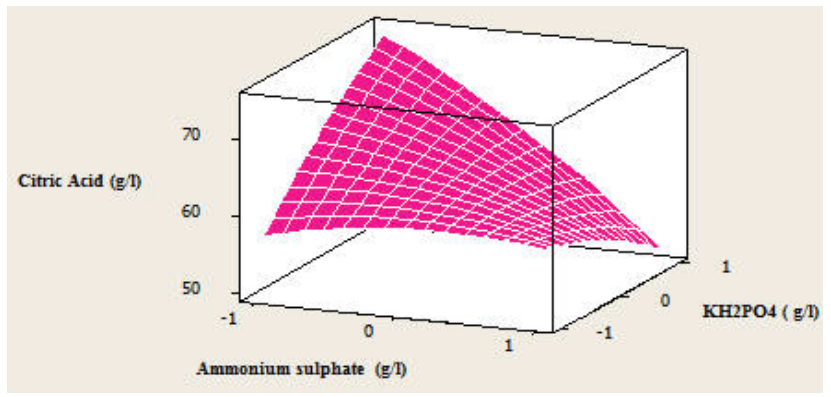

Figure 4: Response surface curve for citric acid production representing the interaction between $\mathrm{KH}_{2} \mathrm{PO}_{4}$ and Ammonium sulphate at 72 hours.

sulphate $\left(\mathrm{NH}_{4}\right)_{2} \mathrm{SO}_{4} 0.2 \mathrm{~g} / \mathrm{l}$ and $\mathrm{KH}_{2} \mathrm{PO}_{4} 3 \mathrm{~g} / \mathrm{l}$. High amounts of $\mathrm{KH}_{2} \mathrm{PO}_{4}$ concentrations favored good yield of citric acid [31,32].

The interactive effect of EDTA and Ammonium sulphate on citric acid production is plotted in Figure 5. Citric acid production in submerged fermentation had a significant effect at low concentration of
Ammonium sulphate and high concentration of EDTA. The maximum production of citric acid was predicted at the Ammonium sulphate $\left(\mathrm{NH}_{4}\right)_{2} \mathrm{SO}_{4} 0.2 \mathrm{~g} / \mathrm{l}$ and EDTA $0.4 \mathrm{~g} / \mathrm{l}$. The data obtained thus indicate that low ammonium sulphate concentrations are essential for good yield in high concentrations of EDTA [33].

Figure 6 is the response surface plot for variation in the citric acid production, as a function of $\mathrm{Mg}^{2+}$ and Ammonium sulphate at 72 hours of fermentation. The production of citric acid was affected by the concentration of $\mathrm{Mg}^{2+}$ and Ammonium sulphate [34,35]. At Low concentration of Ammonium sulphate, medium concentration of $\mathrm{Mg}^{2+}$ had significant effect on increasing citric acid production at submerged fermentation. The maximum production of citric acid was predicted at the $\mathrm{Mg}^{2+}$ and Ammonium sulphate $0.15 \mathrm{~g} / \mathrm{l}$ and $0.2 \mathrm{~g} / \mathrm{l}$.

Figure 7 represents contour plots of citric acid production. Contour plot shows how each response relates to two continuous design variables, while holding the other variables in the model at specified levels.

Figure 8 represents response optimizer plot for citric acid production. Response optimizer plot helps to identify the combination of input variable settings that jointly optimize a single response or a set of responses. Joint optimization satisfies the requirements for all the responses in the set, which is measured by the composite desirability. It provides optimal solution for the input variable combinations [36,37]. Using the response optimizer, the maximum response for citric acid production was $75 \mathrm{~g} / \mathrm{l}$ with a desirability of 1 . The analysis shows that maximum production of citric acid was produced at the following concentrations: Ammonium sulphate $\left(\left(\mathrm{NH}_{4}\right)_{2} \mathrm{SO}_{4}\right) 0.2138$ $\mathrm{g} / \mathrm{l}$, Magnesium $\left(\mathrm{Mg}^{2+}\right) 0.1896 \mathrm{~g} / \mathrm{l}$, Ethylene diamine tetra acetic acid (EDTA) $0.3968 \mathrm{~g} / \mathrm{l}$, Potassium phosphate $\left(\mathrm{KH}_{2} \mathrm{PO}_{4}\right) 3 \mathrm{~g} / \mathrm{l}$.

\section{Conclusions}

The optimization work in this study has given optimal nutrient concentrations and potent organism for citric acid production from

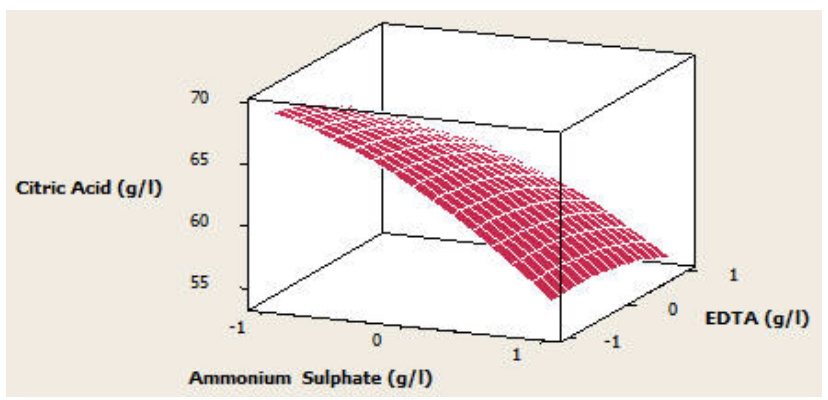

Figure 5: Response surface curve for citric acid production representing the interaction between EDTA and Ammonium sulphate at 72 hours.

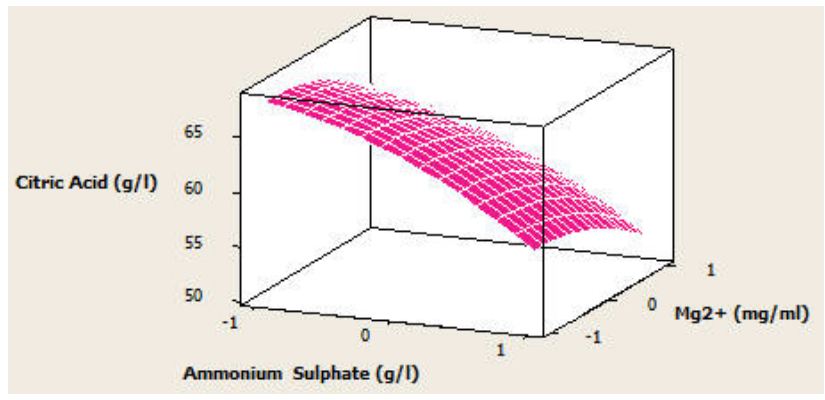

Figure 6: Response surface curve for citric acid production representing the interaction between $\mathrm{Mg}^{2+}$ and Ammonium sulphate at 72 hours. 
Citation: Gopinadh R, Ayyanna C, Ramakrishna Ch, Narayana Saibaba KV, Ravi Vital Kandisa, et al. (2015) Optimization of Chemical Parameters for the Production of Citric acid using Box-Behnken Design. J Bioprocess Biotech 5: 244 doi:10.4172/2155-9821.1000244
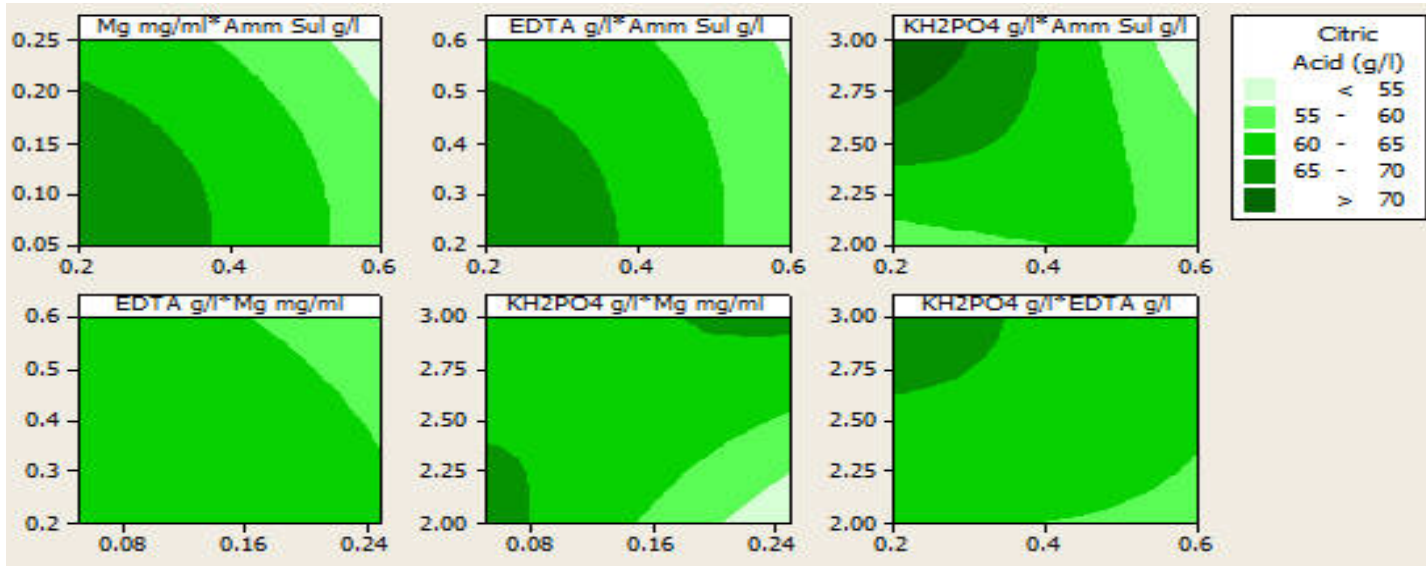

Figure 7: Response contour plots of citric acid.

\begin{tabular}{|c|c|c|c|c|}
\hline $\begin{array}{cc}\text { Optimal } & \mathrm{Hi} \\
\mathrm{D} & \text { Cur } \\
1.0000 & \text { Lo }\end{array}$ & $\begin{array}{c}\text { Ammonium Sulphate, } \mathrm{g} / 1 \\
0.60 \\
{[0.2138]} \\
0.20\end{array}$ & $\begin{array}{c}\mathrm{Mg} 2+, \mathrm{mg} / \mathrm{ml} \\
0.250 \\
{[0.1896]} \\
0.0500\end{array}$ & $\begin{array}{c}\text { EDTA, g/1 } \\
0.60 \\
{[0.3968]} \\
0.20\end{array}$ & $\begin{array}{c}\mathrm{KH} 2 \mathrm{PO} 4, \mathrm{~g} / 1 \\
3.0 \\
{[3.0]} \\
2.0\end{array}$ \\
\hline $\begin{array}{c}\text { Citric Acid, } \mathbf{g} / \mathbf{l} \\
\text { Targ: } 75.0 \\
y=75.0000 \\
d=1.0000\end{array}$ & & & & \\
\hline
\end{tabular}

Figure 7: Response optimizer for citric acid production.

Maduca indica. The statistical based optimization using the BoxBehnken design method was proved to be useful for optimizing the nutrient compositions for citric acid production by mutant Aspergillus niger MTCC 282 grown on potato dextrose agar medium. For citric acid production, Ammonium sulphate $\left(\left(\mathrm{NH}_{4}\right)_{2} \mathrm{SO}_{4}\right)$, had a positive effect as it enhanced cell growth resulting in high production of citric acid, The second-order polynomial model obtained was able to identify citric acid production at specific levels of nutrients within the tested range. The optimum values obtained using the Box-Behnken design were Ammonium sulphate $\left(\left(\mathrm{NH}_{4}\right)_{2} \mathrm{SO}_{4}\right) 0.2138 \mathrm{~g} / \mathrm{l}$, Magnesium $\left(\mathrm{Mg}^{2+}\right)$ $0.1896 \mathrm{~g} / \mathrm{l}$, Ethylene diamine tetra acetic acid (EDTA) $0.3968 \mathrm{~g} / \mathrm{l}$, and Potassium phosphate $\left(\mathrm{KH}_{2} \mathrm{PO}_{4}\right) 3 \mathrm{~g} / \mathrm{l}$. Using the optimal nutrient concentrations, mutant Aspergillus niger MTCC 282 produced the maximum citric acid level of $75 \mathrm{~g} / \mathrm{l}$ of citric acid/ $\mathrm{kg}$ substrate at $\mathrm{pH} 4$.

\section{Acknowledgements}

The author is grateful to the Department of Science \& Technology (DST), Government of India, for funding the research project (No. SB/EMEQ-211/2013) under Science and Engineering Research Board (SERB) and to the GITAM University, Visakhapatnam for their support.

\section{References}

1. Haq I, Khurshid S, Ali K, Ashraf H, Qadeer MA, et al. (2001) Mutation of Aspergillus niger for hyper production of citric acid from black molasses. World J Microbiol Biotechnol 17: 35-37.

2. Gopinadh R, Ayyanna C, Narayana Saibaba KV, Jagadhi R (2012) Statistical experimental design for citric acid production using Madhuca indica. J Pharma Res 5: 374-376.

3. Hang YD, Woodams EE (1998) Production of citric acid from corncobs by Aspergillus niger. Biores Technol 65: 251-253.
4. Alvarez-Vasquez F, González-Alcón C, Torres NV (2000) Metabolism of citric acid production by Aspergillus niger: model definition, steady-state analysis and constrained optimization of citric acid production rate. Biotechnol Bioeng 70: 82-108.

5. Pazouki M, Felse PA, Sinha J, Panda T (2000) Comparative studies on citric acid production by Aspergillus niger and Candida lipolytica using molasses and glucose. Bioproc Eng 22: 353-361.

6. Vandenberghe LPS, Soccol CR, Pandey A, Lebeault JM (2000) Solid-state fermentation for the synthesis of citric acid by Aspergillus niger. Biores Technol 74: $175-178$

7. Panda T, Naidu GSN, Sinha J (1999) Multiresponse analysis of microbiological parameters affecting the production of pectolytic enzymes by Aspergillus niger: a statistical view. Process Biochem 35: 187-195.

8. Anil Kumar PK, Shamala TR, Kshama L, Prakash MH, Joshi GJ, et al. (2007) Bacterial synthesis of poly(hydroxybutyrate- co-hydroxyvalerate) using carbohydrate-rich mahua (Madhuca sp.) flowers. J Appl Microbiol 103: 204-209.

9. Preeti Yadav, Neelima Garg, Deepa Diwedi H (2009) Effect of location of cultivar, fermentation temperature and additives on the physico-chemical and sensory qualities on Mahua (Madhuca indica J. F. Gmel.) wine preparation. Nat Prod Radi 8: 406-418.

10. Xu DB, Kubicek CP, Roch M (1989) A comparison of factors influencing citric acid production by Aspergillus niger grown in submerged culture and on filter paper. Appl Microbiol Biotechnol 30: 444-449.

11. Jianlong W, Ping $L$ (1998) Phytate as a stimulator of citric acid production by Aspergillus niger. Process Biochem 33: 313-316.

12. Hamissa FA, El-Abyad MS, Abdu A, Gad AS (1991) Raising potent UV mutants of Aspergillus niger van Tieghem for citric acid production from beet molasses. Bioresour Technol 39: 209-213.

13. Marier JR, Boulet M (1958) Direct determination of citric acid in milk with an improved pyridine-acetic anhydride method. J Dairy Sci 41: 1683-1692. 
Citation: Gopinadh R, Ayyanna C, Ramakrishna Ch, Narayana Saibaba KV, Ravi Vital Kandisa, et al. (2015) Optimization of Chemical Parameters for the Production of Citric acid using Box-Behnken Design. J Bioprocess Biotech 5: 244 doi:10.4172/2155-9821.1000244

14. Miller GL (1959) Use of Dinitrosalicylic Acid Reagent for Determination of Reducing Sugar. Anal Chem 3: 426-428.

15. Box GEP, Draper NR (1987) Empirical Model-Building and Response Surfaces. John Wiley \& Sons, USA, pp: 249.

16. Box GEP, Wilson KB (1951) On the experimental attainment of optimal conditions. J Roy Statist Soc B 13: 1-45.

17. Ambati P, Ayyanna C (2001) Optimizing medium constitutes and fermentation conditions for citric acid production from palmyra jaggery using response surface method. World J Microbiol Biotechnol 17: 331-335.

18. Ali S, Haq I, Qadeer MA, Iqbal J (2002) Production of citric acid by Aspergillus niger using cane molasses in a stirred fermentor. Electron J Biotechnol 5: 1-5.

19. Tanyildizi MS, Özer D, Murat E (2005) Optimization of a-amylase production by Bacillus sp. using response surface methodology. Process Biochem 40: 22912297.

20. Muralidhar RV, Chirumamila RR, Marchant R, Nigam P (2001) A response surface approach for the comparison of lipase production by Candida cylindracea using two different carbon sources. Biochem Eng J 9: 17-23.

21. Alexander M (1977) Introduction to soil microbiology. Second Edition. John Wiley and Sons Inc., Toronto, Canada. pp: 53-87.

22. AOAC (2002) Official methods of analysis. Association of Analytical Communities, Gaithersburg, MD, USA.

23. Berthouex PM, Brown LC (1994) Statistics for environmental engineers. In: Analysis of variance to compare $\mathrm{k}$ average, CRC press, Boca Raton, USA, pp: 129-170

24. Rodrigues C, Vandenberghe LP, Teodoro J, Pandey A, Soccol CR (2009) Improvement on citric acid production in solid-state fermentation by Aspergillus niger LPB BC mutant using citric pulp. Appl Biochem Biotechnol 158: 72-87.

25. Montgomery DC (2001) Design and Analysis of Experiments, Fifth Edition. John Wiley \& Sons, USA
26. Dutta JR, Banerjee R (2006) Isolation and Characterization of a Newly Isolated Pseudomonas mutant for Protease Production. Braz Arch Biol Technol 49: $37-47$.

27. Haq I, Ali S, Qadeer MA, Iqbal J (2002) Citric acid fermentation by mutant strain of Aspergillus niger GCMC-7 using molasses based medium. Electron J Biotechnol 5: 1-5.

28. Kubicek CP, Röhr M (1977) Influence of manganese on enzyme synthesis and citric acid accumulation by Aspergillus niger European J Appl Microbiol 4: 167173.

29. Kim JW, Barrington S, Sheppard J, Lee B (2004) Effect of initial glucose level on citric acid production by Aspergillus niger NRRL 567 grown on peat moss. Biores Technol 85: 97-100

30. Kristiansen B, Sinclair CG (1979) Production of citric acid in continuous culture Biotechnol Bioeng 21: 297-315.

31. Leangon S, Maddox IS, Brooks JD (2000) A proposed biochemical mechanism for citric acid accumulation by Aspergillus niger Yang No.2 growing in solid state fermentation. World J Microbiol Biotechnol 16: 271-275.

32. Lee JH, Yun HS (1999) Effect of temperature and $\mathrm{pH}$ on the production of citric acid from cheese whey by Aspergillus niger. Kor J Mycol 27: 383-385.

33. Mattey M (1992) The production of organic acids. Crit Rev Biotechnol 12: 87 132.

34. Mirminachi F, Zhang A, Roehr M (2002) Citric acid fermentation and heavy metal ions: Effect of iron, manganese and copper. Acta Biotechnol 22: 363-373

35. Radha S, Babu RH, Sridevi A, Prasad NBL, Narasimha G (2012) Development of mutant fungal strains of Aspergillus niger for enhanced production of acid protease in submerged and solid state fermentation. Euro J Exp Bio 2: 1517-1528.

36. Shu P, Johnson MJ (1948) Citric acid. Ind Eng Chem 40: 1202-1205.

37. Wasay SA (1998) Bioremediation of soils polluted by heavy metals using organic acids. Ph. D. Thesis, Department of Agricultural and Biosystems Engineering, McGill University, Canada. 